\title{
STUDI KELAYAKAN PRAKTEK PERANCANGAN INSTALASI MESIN LISTRIK PADA LABORATORIUM MESIN-MESIN LISTRIK POLITEKNIK NEGERI KUPANG
}

\author{
Rusman Sinaga \\ Jurusan Teknik Elektro Politeknik Negeri Kupang \\ Jalan Adisucipo Penfui Kupang 85361 \\ sinagarusman@gmail.com
}

\begin{abstract}
Abstrak
Studi kelayakan praktek perancangan instalasi mesin listrik pada Laboratorium Mesin Mesin Listrik Politeknik Negeri Kupang bertujuan untuk mengetahui kelayakan sarana dan prasarana Laboratorium Mesin Mesin Listrik khususnya tingkat kelayakan pemakaian sarana peralatan listrik untuk praktek perancangan instalasi mesin listrik. Metode yang digunakan adalah metode penelitian deskriptif, observasional dan evaluatif. Hasil penelitian menunjukkan bahwa tingkat pencapaian keseluruhan komponen baik sarana maupun prasarana yang digunakan dalam pelaksanaan praktek perancangan instalasi mesin listrik masih dalam kategori layak dengan tingkat pencapaian kelayakan maksimum 75, $52 \%$. Komponen penelitian yang paling rendah adalah peralatan utama dalam pelaksanaan praktek perancangan instalasi mesin listrik dengan tingkat pencapaian kelayakan 52 , $33 \%$. Komponen penelitian yang paling tinggi adalah prasarana ruang Laboratorium Mesin Mesin Listrik dengan tingkat pencapaian $87,75 \%$.
\end{abstract}

Kata kunci: Laboratorium, Perancangan Instalasi Mesin Listrik, Praktek, Kelayakan

\section{PENDAHULUAN}

Salah satu kerangka kerja CoT (Center of Technology) adalah menjalankan fungsi laboratorium yang baik dan benar. Efektivitas CoT adalah mengembangkan profesional berkualitas tinggi khususnya di bidang teknik,meningkatkan faktor keberlanjutan lembaga dengan memberdayakan sumber daya dan mendukung industri yang ditargetkan dalam pembangunan serta mengintegrasikan misi lembaga yang relevan dengan kebutuhan industri masa depan (Nurdin, 2012).

Laboratorium adalah tempat untuk melatih mahasiswa dalam hal keterampilan melakukan kegiatan praktikum, demonstrasi, percobaan dan penelitian, ataupun dalam hal pengembangan ilmu pengetahuan dan teknologi. Prioritas pertama yang diperlukan di laboratorium adalah keterampilan dosen dan prananta laboratorium untuk mendemontrasikan peralatan dan yang kedua adalah ketersediaan alat dan bahan praktikum (Wiyogo dan Nopy, 2014).

Penggunaan laboratorium di Perguruan Tinggi belum maksimal dengan tiga permasalahan, yaitu kondisi peralatan laboratorium yang kurang mendapat perhatian, penggunaan laboratorium yang belum optimal dan penerapan Standard Operasional
Procedure (SOP) yang belum dimaksimalkan, dimana SOP sebagai acuan kerja di laboratorium dalam memberikan pelayanan sesuai dengan porsi kerja masig-masing serta Sumber Daya Manusia (SDM) yang belum dimanfaatkan secara maksimal. (Masri et.al 2011)

Upaya peningkatan mutu perguruan tinggi terus menerus dilakukan. Salah satu upaya untuk itu adalah mengembangkan Penjaminan Mutu di perguruan tinggi. Sistem penjaminan mutu mengharapkan tumbuhnya budaya mutu mulai dari bagaimana menetapkan standar, melaksanakan standar, mengevaluasi pelaksanaan standar dan secara kontiniu berupaya meningkatkan standar (Continuous Quality Improvement). Secara umum yang dimaksud dengan penjaminan mutu adalah proses penetapan dan pemenuhan standar pengelolaan secara konsisten dan berkelanjutan sehingga konsumen, produsen dan pihak lain yang berkepentingan memperoleh kepuasan. Dengan demikian, penjaminan mutu perguruan tinggi adalah proses penetapan dan pemenuhan standar pengelolaan pendidikan tinggi secara konsisten dan berkelanjutan, sehingga stakeholders memperoleh kepuasan. Prinsip utama penjaminan mutu ialah mutu adalah tugas setiap orang artinya dalam 
menjalankan pekerjaan sesuai dengan mutu yang distandarkan maka akan hasilnya secara mutu akan terjamin. Misalnya, jika dosen mengajar sesuai dengan kurikulum yang disepakati dalam jumlah pertemuannya sesuai dengan yang distandarkan maka pengetahuan semua mahasiswa dari beberapa kelas yang setingkat akan sama walaupun pemahamannya berbeda dari satu mahasiswa ke mahasiswa yang lainnya (Rinda, 2008). Namun demikian jika peralatan yang dibutuhkan untuk aktualisasi dalam materi perkuliahan praktek di laboratorium tidak lengkap, maka mutu pembelajaran tidak akan dapat tercapai dimana laboratorium digunakan untuk kegiatan pengajaran yang memerlukan praktek ketrampilan tertentu dan atau pengalaman-pengalaman langsung bagi mahasiswa. Dengan perkataan lain, dalam bidang pendidikan dan pengajaran, laboratorium di perguruan tinggi berfungsi untuk memberikan ketrampilan dan pengalaman spesifik sesuai dengan kurikulum yang diterapkan (Sonhadji, 2002), sehingga penelitian ini perlu dilakukan. Hasil penelitian ini dapat mengetahui peralatan praktek yang layak dipakai dan yang tidak layak dipakai dalam pelaksanaan praktek, dengan demikian dapat dilakukan perbaikan dan atau usulan pengadaaan peralatan baru untuk peningkatan kinerja program pembelajaran sesuai dengan standar mutu yang dipersyaratkan dalam pelaksanaan manajemen mutu terutama di Jurusan Teknik Elektro Politeknik Negeri Kupang.

\section{METODE PENELITIAN}

Metode yang digunakan dalam penelitian ini adalah metode penelitian deskriptif, yaitu tipe desain konklusif yang bertujuan untuk mendiskripsikan karakter atau fungsi dari penelitian tentang suatu benda. Penelitian ini juga merupakan penelitian observasional yaitu pengamatan terhadap objek yang diteliti, berusaha mengumpulkan data dari fenomena yang telah muncul untuk memberikan penafsiran yang diperoleh melalui data primer dalam pengumpulan data dan penelitian ini juga merupakan penelitian evaluatif, yaitu penilitian yang mengacu pendekatan studi kasus dalam evaluasi penggunaan prasarana dan sarana peralatan praktek perancangan instalasi mesin listrik.

Populasi penelitian ini adalah seluruh prasarana dan sarana peralatan listrik dalam pelaksanaan praktek perancangan instalasi mesin listrik. Teknik Pengambilan sampel dalam penelitian ini menggunakan conviniance sampling (Nazir, 2009), dengan memperoleh sejumlah sampel peralatan pada Laboratorium Mesin Mesin Listrik (MML).

Variabel yang diamati antara lain adalah: 1) Variabel kuantitas dan kualitas terhadap seluruh prasarana dan sarana peralatan listrik dalam pelaksanaan praktek aplikasi perancangan instalasi mesin listrik. 2)Tabulasi data untuk setiap variabel dalam penelitian ini merupakan tabulasi matriks, dengan metode pengukuran kualitas skala simantik diferensial rasio 1 sampai 4 , untuk mengukur indikator kepentingan dukungan skala rasio tersebut yaitu nilai 1 (sangat tidak layak) sampai dengan nilai 4 (Sangat layak).

Pengumpulan data pada penelitian ini dilakukan dengan observasi dan dengan pengujian peralatan praktek perancangan instalasi mesin listrik yang dipilih sebagai sampel. Untuk mengatasi kelemahankelemahan dalam pengumpulan data, tabulasi data dirancang dalam format tabel data. Data sekunder yang digunakan untuk mendukung data primer diperoleh dari objek penelitian dan studi kepustakaan.

Prosedur penelitian terdiri dari pengumpulan data observasi dan pengujian peralatan, pengolahan data, analisis data dan kesimpulan.

Teknik analisis data yang digunakan adalah analisis Descriptive untuk menggambarkan layak dan atau tidak layaknya peralatan praktek yang diuji untuk seluruh peralatan yang digunakan dalam praktek perancangan instalasi mesin listrik dan relevansinya dengan kurikulum, silabus mata kuliah yang digunakan. Untuk mengetahui tingkat kelayakan peralatan menggunakan proses perhitungan pencapaian kelayakan dilakukan dengan cara mengkalikan hasil bagi skor riil dengan skor ideal dalam persen dengan rumus seperti pada persamaan (1) (Sugiyono, 2013) (Wijayana 2013):

$\mathrm{P}=\frac{s r}{s i} \times 100 \%$

(1)

Dimana:

P: Pencapaian

Sr: Skor Riil

Si: Skor Ideal

Dengan kriteria pencapaian adalah:

Sangat Layak $=76 \%-100 \%$

Layak $=51 \%-75 \%$

Tidak Layak $=26-50 \%$

Sangat Tidak Layak $=0 \%-25 \%$

Peralatan listrik yang diobservasi dan pengujian adalah peralatan digunakan dalam aplikasi praktek perancangan instalasi mesin listrik terdiri dari kontaktor tiga kutub $2 \mathrm{NO}$ dan 2 NC, motor tak serempak rotor sangkar tiga fasa, motor dua kecepatan dahlander, motor 
dua kecepatan dengan dua belitan, motor protection relay, tombol tekan (push button switch) triple pc $1 \mathrm{NO}$ dan $1 \mathrm{NC}$, fuse single pole, MCB tiga fase dan lain-lain.

Kontaktor adalah jenis saklar yang bekerja secara magnetik yaitu kontak bekerja apabila kumparan diberi energi. NEMA(2007), mendefinisikan kontaktor magnetis sebagai alat yang digerakan secara magnetis untuk menyambung dan membuka rangkaian daya listrik. Tidak seperti relay, kontaktor dirancang untuk menyambung dan membuka rangkaian daya listrik tanpa merusak. Beban-beban kontaktor tersebut meliputi lampu, pemanas, transformator, kapasitor, dan motor listrik.

Unit kontaktor terdiri dari koil, beberapa kontak Normally Open (NO) dan beberapa Normally Close (NC). Pada saat satu kontaktor normal, NO akan membuka dan pada saat kontaktor bekerja, NO akan menutup. Sedangkan kontak NC sebaliknya. Koil adalah lilitan yang apabila diberi tegangan akan terjadi magnetisasi dan menarik kontakkontaknya sehingga kontaktor dapat bekerja. Kontaktor yang dioperasikan secara elektromagnetis adalah salah satu mekanisme yang paling bermanfaat yang pernah dirancang untuk penutupan dan pembukaan rangkaian

Spesifikasi kontaktor magnet yang harus diperhatikan adalah kemampuan daya kontaktor ditulis dalam ukuran Watt (kW) yang disesuaikan dengan beban yang dipikul, kemampuan menghantarkan arus dari kontakkontaknya, ditulis dalam satuan ampere, kemampuan tegangan dari kumparan magnet, apakah untuk tegangan 127 Volt atau 220 Volt, begitupun frekuensinya, kemampuan melindungi terhadap tegangan rendah, misalnya ditulis $\pm 20 \%$ dari tegangan kerja.

Keuntungan penggunaan kontaktor magnetis sebagai pengganti peralatan kontrol yang dioperasikan secara manual meliputi: 1) Pada penangan arus besar atau tegangan tinggi, sulit untuk membangun alat manual yang cocok. Sebaliknya, akan relatif sederhana untuk menggunakan kontaktor magnetis yang akan menangani arus yang besar atau tegangan yang tinggi. 2) Kontaktor memungkinkan operasi majemuk dilaksanakan dari satu operator (satu lokasi) dan diinterlocked untuk mencegah kesalahan dan bahaya operasi. 3) Pengoperasian yang harus diulang beberapa kali, dapat digunakan kontaktor yang mudah disinkronisasi dengan time relay. 4) Kontaktor dapat dikontrol secara otomatis dengan alat pilot atau sensor yang sangat peka.5) Tegangan yang tinggi dapat diatasi oleh kontaktor dan menjauhkan seluruhnya dari operator, sehingga meningkatkan keselamatan / keamanan instalasi. 6) Menggunakan kontaktor peralatan kontrol dapat dipasangkan pada titik-titik yang jauh. 7) Menggunakan kontaktor, kontrol otomatis dan semi otomatis memungkinkan dilakukan dengan peralatan seperti kontrol logika yang dapat diprogram seperti Programmable Logic Controller (PLC).

Push Button switchadalah salkar tekan yang berfungsi untuk menghubungkan atau memisahkan bagian-bagian dari suatu instalasi listrik satu sama lain (suatu sistem saklar tekan push button terdiri dari saklar tekan start, stop reset dan saklar tekan untuk emergency. Push button memiliki kontak NC (normally close) dan NO (normally open). Prinsip kerja Push Button adalah apabila dalam keadaan normal tidak ditekan maka kontak tidak berubah, apabila ditekan maka kontak NC akan berfungsi memberhentikan (stop) dan kontak NO akan berfungsi menjalankan (start)yang digunakan pada sistem pengontrolan motor-motor induksi pada industri.

Relay elektromekanis digunakan sebagai alat penghubung pada rangkaian dan pada beberapa aplikasi pada industri dan kontrol proses memerlukan relay sebagai elemen kontrol penting. Relay pengendali elektromekanis adalah saklar magnetis. Relay ini menghubungkan rangkaian beban on dan off dengan pemberian energi elektro magnetis yang membuka dan menutup pada rangkaian. Relay elektromekanis berisi kontak diam dan kontak bergerak. Kontak yang bergerak dipasangkan pada plunger. Kontak ditunjuk sebagai Normally Open (NO) dan Normally Close (NC). Apabila kumparan diberi tenaga, terjadi medan elektromagnetis. Aksi dari medan pada gilirannya menyebabkan plunger bergerak pada kumparan menutup kontak NO dan membuka kontak NC. Kontak NO akan membuka ketika tidak ada arus mengalir pada kumparan, tetapi tertutup secepatnya setelah kumparan menghantarkan arus atau diberi tenaga. Kontak NC akan tertutup apabila tidak diberi daya dan membuka ketika kumparan diberi daya. Level tegangan pada kumparan relay yang diberi tegangan, menyebabkan terhubungnya kontak yang disebut tegangan tarik(pick up voltage). Pada level tegangan pada kumparan relay kembali pada kondisi tidak dioperasikan disebut tegangan lepas(drop out voltage). Kumparan relay dirancang untuk tidak lepas sampai penurunan tegangan pada penurunan tegangan minimum sekitar $85 \%$ dari tegangan kerja. Kumparan relay juga tidak akan menarik (memberi 
energi) sampai tegangan meningkat pada 85 $\%$ tegangan kerja, tanpa merusakan kumparan.

Thermal Over load relay(TOR) adalah proteksi motor listrik dari beban lebih. TOR bekerja berdasarkan pemutus bimetal sesuai dengan arus yang mengalir, semakin tinggi kenaikan temperatur yang menyebabkan terjadinya pembengkokan, maka akan terjadi pemutusan arus, sehingga motor akan berhenti.

Motor induksi sangat banyak digunakan di dalam kehidupan sehari-hari baik di industri maupun di rumah tangga. Motor induksi yang umum dipakai adalah motor induksi tiga phasa dan motor induksi satu phasa. Motor induksi tiga phasa dioperasikan pada sistem tiga phasa dan banyak digunakan didalam berbagai bidang industri, sedangkan motor induksi satu phasa dioperasikan pada sistem satu phasa yang banyak digunakan terutama pada penggunaan untuk peralatan rumah tangga seperti kipas angin, lemari es, pompa air, mesin cuci dan sebagainya karena motor induksi satu phasa mempunyai daya keluaran yang rendah.Motor induksi merupakan motor listrik arus bolak balik (AC) yang paling luas digunakan. Penamaannya berasal dari kenyataan bahwa motor ini bekerja berdasarkan induksi medan magnet stator ke rotornya, dimana arus rotor motor ini bukan diperoleh dari sumber tertentu, tetapi merupakan arus yang terinduksi sebagai akibat adanya perbedaan relatif antara putaran rotor dengan medan putar (rotating magnetic field) yang dihasilkan oleh arus stator.Belitan stator yang dihubungkan dengan suatu sumber tegangan tiga fasa akan menghasilkan medan magnet yang berputar dengan kecepatan sinkron. Medan putar pada stator tersebut akan memotong konduktor-konduktor pada rotor, sehingga terinduksi arus; dan sesuai dengan Hukum Lentz, rotor pun akan ikut berputar mengikuti medan putar stator.Perbedaan putaran relatif antara stator dan rotor disebut slip. Bertambahnya beban, akan memperbesar kopel motor, yang oleh karenanya akan memperbesar arus induksi pada rotor, sehingga slip antara medan putar stator dan putaran rotor pun akan bertambah besar. Jadi, apabila beban motor bertambah, putaran rotor cenderung menurun.Kerja motor induksi adalah berdasarkan prinsip induksi elektromagnet. Kerja motor induksi tergantung pada tegangan dan arus induksi pada rangkaian rotor dari rangkaian stator.

Motor induksi jenis rotor belitan mempunyai rotor dengan belitan kumparan tiga fasa sama seperti kumparan stator. Kumparan stator dan rotor juga mempunyai jumlah kutub yang sama. Rotor yang mempunyai tiga belitan yang mirip dengan belitan stator. Ketiga belitan tersebut biasanya terhubung bintang. Ujung-ujung belitan tersebut dihubungkan dengan slipring yang terdapat pada poros rotor. Belitan-belitan tersebut dihubung singkat melalui sikat (brush) yang menempel pada slipring

Motor induksi rotor sangkar mempunyai rotor dengan kumparan yang terdiri atas beberapa batang konduktor yang disusun sedemikian rupa hingga menyerupai sangkar tupai. Rotor yang terdiri dari sederetan batang-batang penghantar yang terletak pada alur-alur sekitar permukaan rotor. Rotor dan stator membentuk rangkaian magnetis, berbentuk silindris yang simetris dan diantaranya terdapat celah udara. Celah udara antara stator dan rotor, kalau terlalu luas maka effisiensi rendah, sebalikanya jika terlalu sempit menimbulkan kesukaran mekanis pada mesin, apabila ada beda perputaran maka akan menimbulkan slip(Sinaga $R, 2014$ ).

\section{HASIL DAN PEMBAHASAN}

\section{Prasarana Ruang Laboratorium MML}

Berdasarkan lampiran Permendiknas No. 40 Tahun 2008, yang tergolong dalam luas laboratorium adalah luas keseluruhan laboratorium, rasio luas per-peserta didik, dan minimal lebar ruang laboratorium. Hasil penelitian lahan Laboratorium MML pada Jurusan Teknik Elektro Politeknik Negeri Kupang dikelompokkan dalam Tabel 1.

Diskripsi kelayakan ruang Laboratorium MML adalah sebagai berikut:

1) Dari butir pertama tentang aspek kapasitas mahasiswa, standar yang ditetapkan adalah standart untuk jumlah mahasiswa praktek di laboratorium sesuai dengan Standar Mutu Pendidikan PNK adalah 24 Orang. Hasil peninjauan presensi mahasiswa didalam data bahwa ada 19 mahasiswa dalam satu rombongan belajar yang sedang menggunakan praktek perancangan instalasi mesin listrik, berdasarkan hasil tersebut maka didapatkan skor 4

2) Aspek kedua yaitu aspek luas ruangan laboratorium praktek perancangan instalasi mesin listrik. Standar yang ditetapkan adalah $64 \mathrm{~m}^{2}$. Dari hasil peninjauan presensi mahasiswa didapat data bahwa luas ruang laboratorium praktek perancangan instalasi mesin listrik adalah $100 \mathrm{~m}^{2}$. Berdasarkan hasil tersebut maka skor yang didapatkan adalah 4 
3) Butir ketiga yaitu aspek rasio luas ruang per peserta didik. Hasil observasi di lapangan didapat hasil data $5 \mathrm{~m}^{2}$. Standar yang ditetapkan oleh mengenai rasio luas ruang adalah $3 \mathrm{~m}^{2}$ per peserta didik. Berdasarkan hasil tersebut, maka skor yang dihasilkan dari aspek tersebut adalah 4

4) Butir empat, aspek yang ditinjau adalah lebar ruang laboratorium. Hasil pengukuran yang telah dilakukan data bahwa $10 \mathrm{~m}$. Standar yang ditetapkan mengenai lebar ruang laboratorium $8 \mathrm{~m}$. Berdasarkan hasil tersebut, maka skor yang dihasilkan pada aspek tersebut adalah 4

5) Butir lima yaitu luas ruang penyimpanan dan perbaikan. Data observasi yang dilakukan dengan pengukuran langsung luas ruang penyimpanan menghasilkan data $16 \mathrm{~m}^{2}$. Standar yang mengenai luas ruang penyimpanan dan perbaikan adalah $25 \mathrm{~m}^{2}$. Berdasarkan hasil tersebut, maka skor yang dihasilkan adalah 2,56

6) Butir enam yaitu ruang dosen dan instruktur. Data observasi yang dilakukan dengan pengukuran langsung luas ruang dosen dan instruktur adalah $30 \mathrm{~m}^{2}$, sedangkat kriteria standar adalah $36 \mathrm{~m}^{2}$, maka dengan demikian skor untuk butir enam ini adalah 3,33

7) Analisis data mengenai ketercapaian luas lahan pada Ruang Laboratorium praktek perancangan instalasi mesin listrik adalah $\mathrm{P}=(21,06 / 24) \times 100 \%=\mathbf{8 7}, 75 \%$

\section{Sarana Ruang Laboratorium MML \\ a. Perabot}

Perabot adalah sarana pengisi ruang.

Standar mengenai sarana untuk laboratorium MML yang tergolong dalam perabot adalah kursi dan meja. Hasil penelitian mengenai perabot yang berada di Laboratorium MML dikelompokkan dalam Tabel 2.

Deskripsi perabot ruang Laboratorium MML yang diambil dari data hasil observasi pada Tabel 2.

1) Butir pertama yaitu aspek kursi mahasiswa di dalam satu ruang Laboratorium MML. Standar yang adalah :(1) 1 buah/peserta didik; (2) kuat, stabil dan aman; (3)mudah dipindahkan; (4) Ukuran memadahi dan (5) terdapat sandaran. Data hasil observasi yang menunjukkan jumlah keseluruhan kursi adalah 24 buah dan telah memenuhi kriteria yang ditetapkan dalam standar. Berdasarkan hasil tersebut, maka skor yang dihasilkan 4

2) Butir kedua aspek yang diteliti adalah meja praktek di dalam satu ruang laboratorium.
Standar yang ditetapkan meja praktek per kelompok mahasiswa adalah (1) 1 buah/per kelompok dan setiap kelompok maksimal 4 orang mahasiswa (2) kuat, stabil, dan aman, (3) memadahi untuk menampung peralatan praktek;. Hasil observasi yang telah dilakukan adalah jumlah meja di laboratorium MML yang dapat digunakan sesuai dudukan power supplyyang dibutuhkan adalah 6 buah dan semua kriteria yang ada dalam standar telah terpenuhi. Berdasarkan hasil tersebut, maka skor yang dihasilkan pada aspek tersebut adalah 4.

3) Butir ketiga aspek yang diteliti adalah kursi dosen/instruktur. Standar yang ditetapkan adalah: (1) 1 buah/dosen; (2) kuat, stabil dan aman; (3)mudah dipindahkan; (4) Ukuran memadahi dan (5) terdapat sandaran. Data hasil observasi yang menunjukkan jumlah keseluruhan kursi dosen/instruktur adalah 4 buah. Berdasarkan hasil observasi kursi dosen memenuhi kriteria yang ditentukan pada standar, maka skor yang dihasilkan 4

4) Butir kempat adalah meja dosen/instruktur. Standar yang ditetapkan adalah (1) 1 buah/dosen; (2) kuat, stabil, aman; (3) mudah dipindahkan dan (4) ukuran memadahi. Hasil observasi menunjukkan bahwa dalam ruang Laboratorium MML terdapat 3 buah meja dosen/Instruktur, sementara dosen yang melaksanakan praktek sesuai dengan sejumlah mata kuliah praktek adalah minimal 4 buah meja. Berdasarkan hasil observasi tersebut, maka skor yang dihasilkan dari keadaan tersebut adalah 3

5) Demikian selanjutnya untuk butir keima dan seterusnya yang antara lain seperti Kursi PLP, Meja PLP, Komputer Administrasi, Printer, UPS dan jam dinding, semuanya memenuhi kriteria standar sehingga skor 4

6) Dari hasil analisis dikriptif diatas maka untuk perabot ruang Laboratorium MML memiliki rata-rata cencapaian $97.5 \%$

\section{b. Peralatan utama praktek perancangan instalasi mesin listrik}

Peralatan utama praktek perancangan instalasi mesin listrik antara lain ditunjukkan pada Tabel 3. Peralatan ini adalah merupakan peralatan inti dalam melaksanakan praktek perancangan instalasi listrik.

Diskripsi hasil observasi dan berdasarkan pengujian peralatan utama dalam melaksanakan praktek perancangan instalasi mesin listrik adalah sebagai berikut: 
1) Dari seluruh butir komponen penelitian yang dikategorikan tidak layak dimana tingkat pencapaian dibawah 50\% antara lain adalah motor asinkron 3 pasa, motor dua kecepatan dahlander, motor dua kecepatan dengan dua belitan, thermal overload, tombol tekan triple box. Berdasarkan hasil pengujian peralatan ditemukan bahwa sebanyak 8 unit kontraktor tiga kutub dalam kondisi rusak, dimana pengadaan peralatan ini diadakan tahun 1990, sehingga peralatan kontaktor tersebut sudah tidak layak pakai lagi. Terdapat dua unit termal overload relay dalam kondisi rusak dan tiga unit tombol tekan triple box juga dalam kondisi rusak serta 20 buah kabel penghubung dalam kondisi rusak.

2) Skor tertinggi dalam peralatan praktek perancangan instalasi listrik adalah peralatan MCB tiga pasa dengan skor 4, dimana peralatan ini dinilai memadai

3) Rerata tingkat pencapaian kelayakan peralatan utama dalam melaksanakan praktek perancangan instalasi listrik adalah $52,33 \%$

\section{c. Peralatan Multimedia}

Selain peralatan utama dalam melaksanakan praktek perancangan instalasi listrik, untuk menyampaikan instruksi praktektek maupun penjelasan-penjelasan teori pendukung, peralatan multimedia di Laboratorium MML tidak kalah penting. Peralatan multimedia dimaksud seperti pada Tabel 4.

Diskripsi hasil observasi untuk perlatan multimedia di ruang Laboratorium MML adalah sebagai berikut:

1) Keseluruhan komponen penelitian untuk peralatan multimedia ini rata-rata skor maksimum 4, kecuali komputer tidak terdapat di ruang laboratorium, yang ada hanya komputer yang berada di ruang Dosen/Instruktur

2) Dengan demikian rerata pencapaian kelayakan untuk peralatan multimedia di ruang laboratorium masin-mesin listrik adalah $80 \%$, kategori sangat layak

\section{d. Peralatan Lain}

Selain peralatan multimedia, terdapat sejumlah peralatan pendukung dalam melaksanakan praktek perancangan instalasi mesin listrik seperti pada tabel 5.

Diskripsi hasil observasi untuk perlatan pendukung lain yang ada di Laboratorium MML adalah sebagai berikut:

1) Peralatan pendukung yang sangat
dibutuhkan di Laboratorium MML adalah genset automatic atau ATS, dimana jika terjadi pemadaman listrik dari PLN diharapkan secara otomatis genset tersebut dapat beroperasi sehingga praktek di Laboratorium MML dapat berjalan dengan baik, namun demikian karena ketidak adaan peralatan genset ini, beberapa kali praktek harus ditunda. Karena peralatan ini tidak ada maka hasil observasi menunjukkan angka tingkat capaian sama dengan nol

2) Komponen jam dinding hanya ada di ruang instruktur/dosen, seharusnya jam dinding juga ditempelkan di dinding laboratorium, sehingga seluruh mahasiswa dapat melihat dan menepati waktu, skor untuk peralatan pendukung ini adalah nol.

3) Skor untuk peralatan pendukung lainnya seperti AC,Kipas amgin, tempat sampah, sudah memenuhi standard dengan skor 4

4) Rerata tingkat pencapaian Peralatan pendukung Lain di Laboratorium MML adalah $60 \%$.

\section{B. Rekapitulasi Hasil Pencapaian Studi kelayakan Pelaksanaan Praktek PIML}

Sesuai hasil observasi sarana dan prasarana serta berdasatkan pengujian peralatan utama dalam pelaksanaan praktek perancangan instalasi mesin listrik ditetapkan rekapitulasi hasil seperti pada Tabel 6.

Berdasarkan rekapitulasi hasil observasi dalam penelitian ini didiskripsikan sebagai berikut:

1) Tingkat pencapaian keseluruhan komponen penelitian adalah 75,52 \% dalam range kategori layak, belum mencapai kategori sangat layak

2) Komponen penelitian yang paling rendah adalah peralatan utama dalam pelaksanaan praktek perancangan instalasi mesin listrik dengan tingkat pencapaian $52,33 \%$

3) Komponen penelitian yang paling tinggi adalah prasarana ruang laboratorium mesin listrik dengan tingkat pencapaian $87,75 \%$ dengan kategori sangat layak dalam pelaksanaan praktek perancangan instalasi mesin listrik

persentase pencapaian dalam rekapitulasi seluruh komponen diatas digambarkan seperti pada Gambar 1. 
Tabel 1. Prasarana ruang Laboratorium MML

\begin{tabular}{rlrrrrr}
\hline No & \multicolumn{1}{c}{ Komponen Penelitian } & KS & HO & SI & SR & P (\%) \\
\hline 1 & Kapasitas Mahasiswa & 24 & 19 & 4 & 3,17 & 79,17 \\
2 & Luas Ruang Lab & 64 & 100 & 4 & 4,00 & 100,00 \\
3 & Rasio Ruang Lab/Mahasiswa & 3 & 5 & 4 & 4,00 & 100,00 \\
4 & Lebar Ruang Lab & 8 & 10 & 4 & 4,00 & 100,00 \\
5 & Luas Ruang Penyimpanan/perbaikan & 25 & 16 & 4 & 2,56 & 64,00 \\
6 & Luas Ruang Dosen/Instruktur & 36 & 30 & 4 & 3,33 & 83,33 \\
\hline Total Skor & \multicolumn{5}{c}{24} & 21,06 \\
\cline { 1 - 2 }
\end{tabular}

Rerata Pencapaian

Keterangan:KS: Kriteria Standar, HO: Hasil Observasi, SI : Skor Ideal, SR : Skor Rilil $\mathrm{P}$ : Pencapaian

Tabel 2. Perabot ruang Laboratorium MML

\begin{tabular}{rlrrrrr}
\hline No & Komponen Penelitian & KS & HO & SI & \multicolumn{1}{c}{ SR } & P \\
\hline 1 & Kursi Mahasiswa & 24 & 24 & 4 & 4,00 & 100,00 \\
2 & Meja Praktek & 6 & 6 & 4 & 4,00 & 100,00 \\
3 & Kursi Dosen/Instruktur & 4 & 4 & 4 & 4,00 & 100,00 \\
4 & Meja Dosen/Instruktur & 4 & 3 & 4 & 3,00 & 75,00 \\
5 & Kursi PLP & 2 & 2 & 4 & 4,00 & 100,00 \\
6 & Meja PLP & 2 & 2 & 4 & 4,00 & 100,00 \\
7 & Komputer Adm & 1 & 1 & 4 & 4,00 & 100,00 \\
8 & Printer & 1 & 1 & 4 & 4,00 & 100,00 \\
9 & UPS & 1 & 1 & 4 & 4,00 & 100,00 \\
10 & Jam Dinding & 1 & 1 & 4 & 4,00 & 100,00 \\
\hline Total Skor & & & 40 & 39,00 & \\
\cline { 1 - 3 }
\end{tabular}

Rerata Pencapaian 
Tabel 3. Peralatan Utama Praktek Perancangan Instalasi Mesin Listrik

\begin{tabular}{|c|c|c|c|c|c|c|c|}
\hline No & Komponen Penelitian & KS & $\mathrm{HO}$ & SI & SR & $\mathrm{P}$ & Keterangan \\
\hline 1 & Kontaktor tiga kutub & 20 & 12 & 4 & 2,40 & 60,00 & 8 Unit Rusak \\
\hline 2 & Motor Asinkron 3 pasa & 5 & 2 & 4 & 1,60 & 40,00 & \\
\hline 3 & Motor Dua Kecepatan Dahlander & 5 & 1 & 4 & 0,80 & 20,00 & \\
\hline 4 & Motor Dua Kecepatan Dua belitan & 5 & 1 & 4 & 0,80 & 20,00 & \\
\hline 5 & Thermal Overload Relay & 5 & 2 & 4 & 1,60 & 40,00 & 2 Unit Rusak \\
\hline 6 & Tombol tekan Triple box & 15 & 5 & 4 & 1,33 & 33,33 & 3 Unit Rusak \\
\hline 7 & Fuse Single Pole & 5 & 3 & 4 & 2,40 & 60,00 & \\
\hline 8 & MCB tiga pasa & 5 & 5 & 4 & 4,00 & 100,00 & \\
\hline 9 & Power Supply AC 3 phasa & 5 & 3 & 4 & 2,40 & 60,00 & \\
\hline 10 & Kabel Penghubung & 100 & 90 & 4 & 3,60 & 90,00 & 20 Rusak \\
\hline \multicolumn{2}{|c|}{ Total Skor } & & & 40 & 20,93 & & \\
\hline \multicolumn{2}{|c|}{ Rerata Pencapaian (\%) } & & & & & 52,33 & \\
\hline
\end{tabular}


Tabel 4. Peralatan Multimedia di Ruang Laboratorium MML

\begin{tabular}{rlrrrrr}
\hline No & \multicolumn{1}{c}{ Komponen Penelitian } & KS & HO & SI & SR & \multicolumn{1}{c}{ P } \\
\hline 1 & Papan Tulis & 1 & 1 & 4 & 4,00 & 100,00 \\
2 & LCD Projector & 1 & 1 & 4 & 4,00 & 100,00 \\
3 & Layar LCD Projector & 1 & 1 & 4 & 4,00 & 100,00 \\
4 & Komputer & 1 & 0 & 4 & 0,00 & 0,00 \\
5 & Titik Akses Internet & 1 & 1 & 4 & 4,00 & 100,00 \\
\hline Total Skor & & & $\mathbf{2 0}$ & $\mathbf{1 6}$ & \\
\cline { 1 - 2 }
\end{tabular}

Rerata Pencapaian (\%) 80,00

Tabel 5. Peralatan lain di Laboratorium MML

\begin{tabular}{rlcrrrr}
\hline No & \multicolumn{1}{c}{ Komponen Penelitian } & KS & HO & SI & SR & \multicolumn{1}{c}{ P } \\
\hline 1 & Tempat sampah & 1 & 1 & 4 & 4,00 & 100,00 \\
2 & Jam Dinding & 1 & 0 & 4 & 0,00 & 0,00 \\
3 & Air Conditioner & 2 & 2 & 4 & 4,00 & 100,00 \\
4 & Kipas Angin & 2 & 2 & 4 & 4,00 & 100,00 \\
5 & Genset Automatic/ATS & 1 & 0 & 4 & 0,00 & 0,00 \\
\hline Total Skor & & & $\mathbf{2 0 , 0 0}$ & $\mathbf{1 2 , 0 0}$ & \\
\cline { 1 - 2 } Rerata Pencapaian (\%) & & & & & $\mathbf{6 0 , 0 0}$ \\
\hline
\end{tabular}

Tabel 6. Rekapitulasi pencapaian studi kelayakan praktek PIML

\begin{tabular}{rlrrr}
\hline No & \multicolumn{1}{c}{ Komponen Penelitian } & SI & TS & P \\
\hline 1 & Prasarana ruangan Laboratorium MML & 24 & 21,06 & 87,75 \\
2 & Perabot ruang Laboratorium MML & 40 & 39,00 & 97,50 \\
3 & Peralatan utama praktek PIML & 40 & 20,93 & 52,33 \\
4 & Peralatan multimedia Laboratorium MML & 20 & 16,00 & 80,00 \\
5 & Peralatan lain untuk ruang Laboratorium MML & 20 & 12,00 & 60,00 \\
\hline Total Skor & 144 & 108,99 \\
\hline
\end{tabular}

Rerata Pencapaian (\%) 


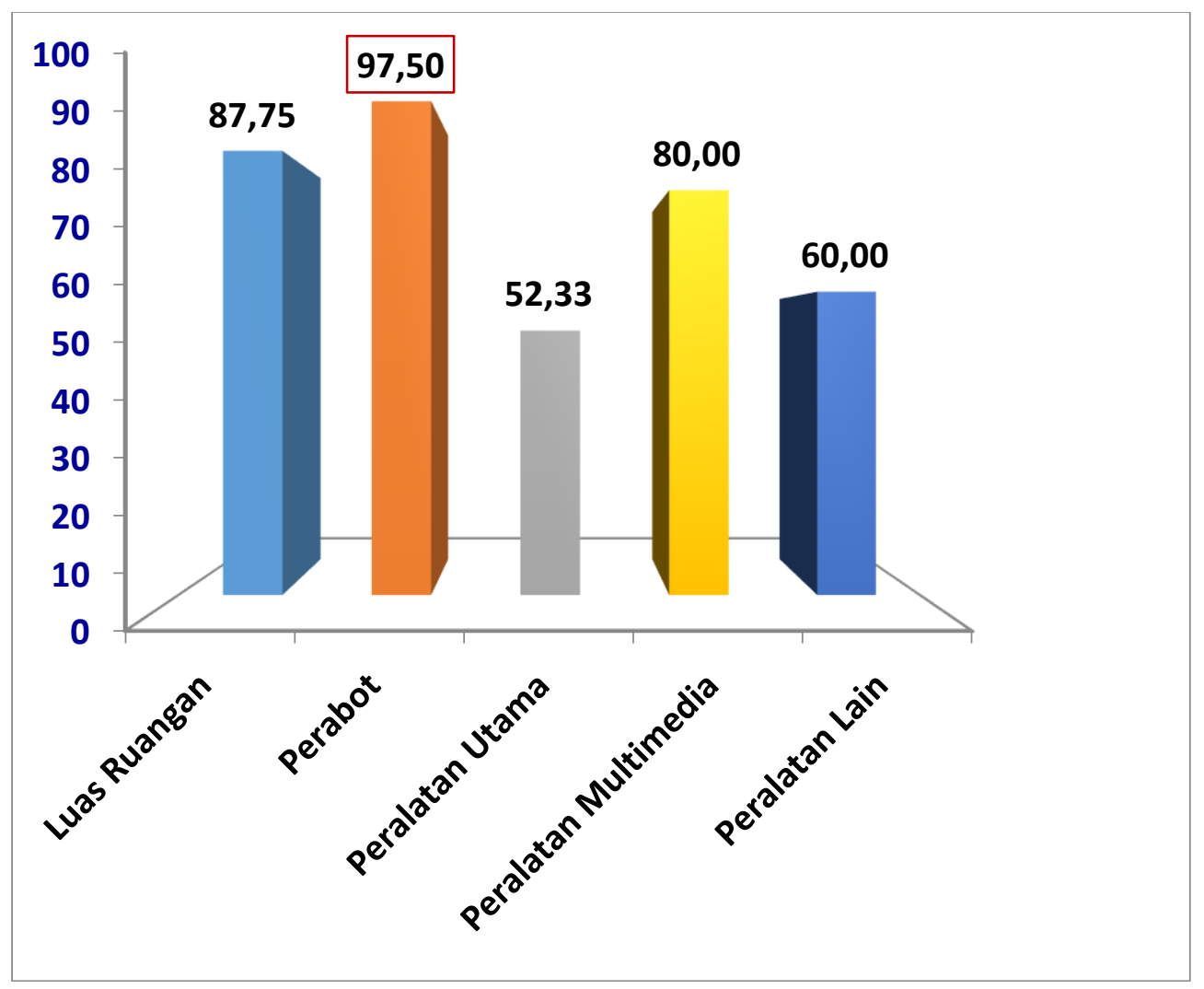

Gambar 1. Tingkat pencapaian kelayakan dalam melaksanakan praktek PIML

\section{PENUTUP}

\section{A. Kesimpulan}

Tingkat pencapaian keseluruhan komponen baik sarana maupun prasarana yang digunakan dalam pelaksanaan praktek perancangan instalasi mesin listrik masih dalam kategori layak dengan tingkat pencapaian kelayakan maksimum $75,52 \%$.

Komponen penelitian yang paling rendah adalah peralatan utama dalam pelaksanaan praktek perancangan instalasi mesin listrik dengan tingkat pencapaian kelayakan $52,33 \%$.

Komponen penelitian yang paling tinggi adalah prasarana ruang laboratorium mesin listrik dengan tingkat pencapaian 87,75\%, tingkat pencapaian ini mengindikasikan kategori sangat layak dalam pelaksanaan praktek perancangan instalasi mesin listrik

\section{B. Saran}

Dari hasil penelitian ini, untuk meningkatkan mutu sarana laboratorium Mesin Mesin Listrik di Politeknik Negeri Kupang, khususnya dalam pelaksanaan praktek perancangan instalasi mesin listrik disarankan:

agar mengusulkan peralatan terbaru khususnya untuk peralatan utama dalam pelaksanaan praktek di laboratorium mesinmesin listrik. Perlu penambahan peralatan khususnya untuk motor-motor listrik, baik untuk motor dua kecepatan maupun beberapa jenis motor induksi lainnya.

Perlu pengadaan generator set (Genset) yang berkapasitas disesuaikan dengan kebutuhan daya pada laboratorium mesinmesin listrik yang dilengkapi dengan automatisasi genset (ATS)

\section{UCAPAN TERIMAKASIH}

Penulis mengucapkan terimakasih kepada Politeknik Negeri Kupang yang telah memberikan dukungan materil, sarana dan prasarana sehingga penelitian ini dapat dilaksanakan. 


\section{DAFTAR PUSTAKA}

Masri M, Darminto, Fauziah I. (2011). Service Quality Analysis of Laboratory of Department of Chemistry, Faculty of Mathematics and Natural Sciences. Jurnal Chemica.12 (2)27 - 35.

NazirM. (2009). Metode Penelitian. Jakarta: Ghalia Indonesia

[NEMA] National Electrical Manufacturers Assosiation. 2007. Diagram, Device, Disaignations and Symbols for Industrial Control and Systems. Rosslin Virginia: National Electrical Manufacturers Assosiation.

Nurdin M. (2012). Center of Technology (COT) for Industrial Product Development through Collaboration and Partnership in Polytechnic Education. Procedia - Social and Behavioral Sciences. 52, 207-216.

Rinda H. \& Gerardus P. (2008). Model Sistem Penjaminan Mutu \& Proses Penerapannya di Perguruan Tinggi. Yogyakarta: Graha IImu.

Sinaga R.(2014). Perancangan Instalasi Mesin Listrik, Jurusan Teknik Elektro. Kupang: Politeknik Negeri Kupang

Sonhadji A.( 2002). Laboratorium Sebagai Basis Pendidikan Teknik Di Perguruan Tinggi. Malang: Universitas Negeri Malang

Sugiyono. (2013). Metode Penelitian Kuantitatif, Kualitatif, dan R\&D. Bandung: Alfabeta

Wijayana B.P.(2013). Studi Kelayakan Sarana Dan Prasarana Laboratorium. Yogjakarta: UNY

Wiyogo \& Nopy Y. (2014). Application of Quality Function Deployment on Practicum Needs Analysis of Mechanical Engineering Education Program. Jurnal Pendidikan Teknologi dan Kejuruan BALANGA. 2 (2):23-32 